\title{
TIMP3 and CCNA1 hypermethylation in HNSCC is associated with an increased incidence of second primary tumors
}

\author{
Marianna Marconato Rettori ${ }^{1 \dagger}$, Ana Carolina de Carvalho ${ }^{1 \dagger}$, Ana Luiza Bomfim Longo ${ }^{1}$, \\ Cleyton Zanardo de Oliveira², Luiz Paulo Kowalski ${ }^{3}$, André Lopes Carvalho ${ }^{4}$ and André Luiz Vettore 1,5* $^{*}$
}

\begin{abstract}
Background: Hypermethylation in the promoter regions is associated with the suppression of gene expression and has been considered a potential molecular marker for several tumor types, including head and neck squamous cell carcinomas (HNSCC).

Methods: To evaluate the gene hypermethylation profile as a prognostic marker, this retrospective study used a QMSP approach to determine the methylation status of 19 genes in 70 HNSCC patients.

Results: The methylation profile analysis of primary HNSCC revealed that genes CCNA1, DAPK, MGMT, TIMP3 and SFRP1 were frequently hypermethylated, with high specificity and sensitivity. TIMP3 and CCNA1 hypermethylation was significantly associated with lower rates of second primary tumor-free survival ( $p=0.007$ and $p=0.001$; log-rank test, respectively).

Conclusion: This study, for the first time, presents CCNA1 and TIMP3 hypermethylation as a helpful tool to identify HNSCC subjects at risk of developing second primary carcinomas.
\end{abstract}

Keywords: Head and neck cancers, HNSCC Prognostic Marker, DNA methylation, epigenetics, TIMP3, CCNA1

\section{Background}

Head and neck squamous cell carcinomas (HNSCC) are the sixth most common non-skin cancer in the world, with an incidence of 600,000 cases per year [1]. Despite improvements in diagnosis and management of HNSCC patients, through combined efforts in prevention, surgery, radiotherapy and chemotherapy, a significant percentage of patients still have a poor prognosis with a five-year survival of only $50 \%$ [2].

High recurrence and second primary tumor (SPT) rates are common reasons for HNSCC treatment failure [3,4]. With an incidence of $17-30 \%$ and an annual risk of $3-10 \%$ [4-6], the development of SPT significantly contributes to a worse prognosis and cancer-associated death for HNSCC

\footnotetext{
* Correspondence: andre.vettore@gmail.com

${ }^{\dagger}$ Equal contributors

'Cancer Molecular Biology Laboratory, Department of Biological Sciences, Federal University of São Paulo, 04039-020, São Paulo, Brazil

${ }^{5}$ Cancer and Stem Cell Biology Program, Duke-NUS Graduate Medical School, 169857, Singapore, Singapore

Full list of author information is available at the end of the article
}

patients $[4,7-10]$. The SPT development is in accordance with the field cancerization theory, which refers to the presence of malignant or premalignant changes in the entire apparently normal mucosa in response to carcinogen exposition, especially tobacco and alcohol [11].

Some potential molecular markers have been evaluated aiming to identify genetic abnormalities associated with a possible prediction of SPT [12-14]. Aberrant DNA methylation (hypermethylation) of gene promoter region acts as an alternative to mutations in disrupting tumor suppressor gene function [15]. This process involves the addition of a methyl group to the carbon 5 position of the cytosine ring in CpG dinucleotides catalyzed by DNA methyltransferases [16]. It is associated with several changes in chromatin structure and the recruitment of proteins to the methylated sites. The methylation usually leads to the obstruction of the promoter region, hindering gene transcription and subsequently causing gene silencing [17]. Genes involved in the cell cycle control, DNA repair, apoptosis, cell adhesion and signal transduction have already been 
described as inactivated by aberrant promoter methylation in different human cancers $[18,19]$ including HNSCC [20,21]. DNA hypermethylation can be measured in tissue samples or body fluids using a real-time quantitative methylation-specific PCR (QMSP) approach. The ability to quantify methylation allows the delineation of clinically meaningful threshold values of methylation to improve sensitivity and specificity in the detection of tumor-specific signal $[16,22,23]$.

We have previously reported that evaluation of methylation profile in salivary rinses is as an independent prognostic marker for local recurrence-free survival in patients with HNSCC, justifying the use of DNA hypermethylation detection in saliva as a tool for identifying and monitoring HNSCC patients' subgroups with high risk of presenting local recurrence [24].

Patients who develop an SPT have a significantly worse prognosis and increased risk of death by cancer. Thus, the best strategies to improve patient management are prevention, early diagnosis, an appropriate treatment choice and close follow-up of patients, with deep investigation of all suspicious lesions. The feasibility of using molecular markers able to predict the outcome of HNSCC, through the evaluation of gene methylation patterns in samples from HNSCC patients, largely opens the potential for a better therapy choice and closer surveillance after treatment of the primary tumor. Thus, in this retrospective study, we sought to characterize the promoter methylation status of 19 genes in primary tumors from HNSCC patients, and evaluate its clinical significance and usefulness as a prognostic biomarker, especially regarding the prediction of the development of second primary tumors in HNSCC patients.

\section{Methods}

\section{Patients}

This retrospective study involved tissue specimens from 70 HNSCC patients who underwent tumor resection between 2006 and 2010 at the Department of Head and Neck Surgery of the A. C. Camargo Hospital (São Paulo, Brazil). These samples were available at the tumor bank of the A. C. Camargo Hospital. Only patients diagnosed with primary HNSCC, not previously treated, that were over 18 years of age, treated with curative intent and presenting with tumors at oral cavity, larynx, or pharynx were included in the study. All samples were checked microscopically for the presence of neoplastic tissue and the absence of contaminating normal mucosa. Tissue samples were snap-frozen in liquid nitrogen within 30 minutes after resection and stored at $-80^{\circ} \mathrm{C}$. For the control group, 60 salivary rinse samples from healthy accompanying patients (68\% men, median age 46.3 and 38\% smokers) were collected at the Barretos Cancer Hospital (São Paulo, Brazil).
The experimental protocol was approved by the Ethics Committees of the A. C. Camargo Hospital and performed in accordance with the ethical guidelines of the 1975 Declaration of Helsinki. Clinical-pathological information was collected from the patients' medical records. Smoking was defined as use of tobacco, chewable or smoked, for at least 1 year continuously. Alcohol use was defined as intake of more than 2 alcoholic drinks per day, for at least 1 year continuously.

\section{Sample collection and DNA extraction}

Genomic DNA was isolated from the tissue samples using the TRIzol reagent (Invitrogen, Frederick, MD) following manufacturer's recommendations. Salivary rinses were obtained by swishing and gargling with $10 \mathrm{~mL}$ normal saline solution ( $\mathrm{NaCl} 0.9 \%)$. Samples were centrifuged for $10 \mathrm{mi}$ nutes at 1,500 rpm, cell pellets were suspended in $300 \mu \mathrm{L}$ of water and stored at $-70^{\circ} \mathrm{C}$. DNA from exfoliated cells present in salivary rinse was extracted by digestion with $50 \mathrm{mg} / \mathrm{mL}$ proteinase $\mathrm{K}$ (Invitrogen) in the presence of $1 \%$ SDS at $48^{\circ} \mathrm{C}$ overnight, followed by phenol/chloroform extraction and ethanol precipitation.

\section{Bisulfite treatment}

Bisulfite treatment of DNA converts unmethylated cytosines to uracil, while the methylated ones remain as cytosines. Sodium-bisulfite conversion of $2 \mu \mathrm{g}$ of DNA was performed according a previously described method with modifications [25]. In brief, $2 \mu \mathrm{g}$ of DNA from each sample was denatured in $0.2 \mathrm{M} \mathrm{NaOH}$ for $20 \mathrm{~min}$ at $50^{\circ} \mathrm{C}$ (in a total volume of $20 \mu \mathrm{L}$ ). The denatured DNA was diluted in $500 \mu \mathrm{L}$ of a freshly made bisulfite solution (2.5 M sodium metabisulfite, $125 \mathrm{mM}$ hydroquinone, $350 \mathrm{mM}$ sodium chloride, pH5.0) and incubated for $3 \mathrm{~h}$ at $70^{\circ} \mathrm{C}$ in the dark. Bisulfite-modified DNA was purified using the Wizard DNA Clean-Up System (Promega) according to the manufacturer's instructions and eluted in $45 \mu \mathrm{L}$ of water at $80^{\circ} \mathrm{C}$. After treatment with $\mathrm{NaOH}$ (final concentration $0.3 \mathrm{M}$ ) for $10 \mathrm{~min}$ at room temperature, the treated DNA was precipitated by the addition of $75 \mu \mathrm{L}$ of ammonium acetate, 2.5 volumes of ethanol, and $2 \mu \mathrm{L}$ of glycogen $(5 \mathrm{mg} / \mathrm{mL})$. Each resulting DNA pellet was washed with $70 \%$ ethanol, dried, dissolved in $110 \mu \mathrm{L}$ of water, and stored at $-80^{\circ} \mathrm{C}$.

\section{Target gene selection}

A total of 19 genes were selected for the examination of methylation abnormalities. The panel included genes reported as targets for epigenetic silencing in different human cancers. All the genes evaluated in this study present tumor suppressor activities and their silencing could contribute to the tumorigenesis process. Among these genes are CCNA1, CCND2, CDKN2B, DAPK, DCC, COX2 and $S O C S 1$ which are involved in cell cycle control and apoptosis, CDH1, THBS1 and TIMP3 in cell adhesion, $R A R \beta$ 
and TGF $\beta 2$ in signal transduction processes, MGMT in DNA repair, CALCA and MT1G in cell-cell signaling processes, HIC1, SFRP1, UCHL1 and HIN1 in cell differentiation and proliferation. It has been shown that the expression of these genes may be affected by aberrant promoter methylation in association with transcription silencing in different types of human malignancies [20,26-31].

\section{Quantitative methylation-specific PCR}

The quantitative methylation-specific PCR analyses (QM SP) were conducted as previously described [32]. Basically, $30 \mathrm{ng}$ of bisulfite-modified DNA (this is the amount of material enough to ensure that a methylated sample will be detected, given the sensitivity thresholds of the technique) was used as template in fluorogenic QMSP assays carried out in a final volume of $20 \mu \mathrm{L}$ in 96-well plates in the ABI Prism SDS 7500 (Applied Biosystems). PCR was performed in separate wells for each primer/probe set and each sample was run in triplicate. The final reaction mixture contained $3 \mu \mathrm{L}$ of bisulfite-modified DNA, $1.2 \mu \mathrm{mol} / \mathrm{L}$ of forward and reverse primers, $200 \mathrm{nmol} / \mathrm{L}$ of the probe, $0.5 \mathrm{U}$ of platinum Taq polymerase (Invitrogen), $200 \mu \mathrm{mol} / \mathrm{L}$ dNTPs, $16.6 \mathrm{nmol} / \mathrm{L}$ ammonium sulfate, $67 \mathrm{mmol} / \mathrm{L}$ Trizma, $6.7 \mathrm{mmol} / \mathrm{L}$ magnesium chloride (2.5 mmol/L for CDKN2A), $10 \mathrm{mmol} / \mathrm{L}$ mercaptoethanol, $0.1 \%$ DMSO, and $1 \mathrm{X}$ ROX dye (Invitrogen). PCR was conducted with the following conditions: $95^{\circ} \mathrm{C}$ for $2 \mathrm{~min}$, followed by 45 cycles at $95^{\circ} \mathrm{C}$ for $15 \mathrm{sec}$. and $60^{\circ} \mathrm{C}$ for $1 \mathrm{~min}$. Each plate included patient DNA samples, multiple water blanks and serial dilutions (30-0.0003 ng) of a positive control allowing the construction of calibration curves. Leukocyte DNA obtained from a healthy individual was methylated in vitro using SssI methyltransferase (New England Biolabs) to generate methylated DNA at all CpG to be used as positive control.

Primers and probes were obtained from the literature and specifically amplify the promoter regions of the 19 genes of interest and the internal control gene, $A C T B$. Primer and probe sequences are provided in Additional file 1: Table S1. The relative DNA methylation level of the 19 genes in each sample was determined as a ratio of methylation specific PCR-amplified gene to $A C T B$ and then multiplied by 100 for easier tabulation (average value of triplicates of gene of interest divided by the average value of triplicates of $A C T B \times 100$; reactions presenting standard deviation of the triplicates greater than 0.5 was repeated). A cut-off value of $\geq 0.1 \%$ was used to score the samples as positive ones for the genes CCNA1, MGMT and SFRP1, while for DAPK and TIMP3, no cut-off values were used, since these genes were not methylated at all in the saliva samples evaluated from controls. Cut-off values were used to optimize sensitivity and specificity levels to better distinguish HNSCC patients from healthy individuals and to exclude very low-level background readings that can occur in certain individual for certain genes [18].

\section{Statistical analysis}

Statistical analysis was performed using the software SPSS 19.0 for Windows. Categorical variables were compared using Pearson's Chi-square test or Fisher's exact test, as appropriate. Survival curves were calculated by Kaplan-Meier method and differences between groups were compared using the log-rank test. Second primary tumors were defined according to the criteria proposed by Warren and Gates [33]. The second primary tumor control time was defined as the interval between the date of initial treatment and the diagnosis of second primary tumor, while the overall survival interval was defined as the interval between the date of initial treatment and the last follow up visit/information or death. For all analysis we considered statistical significance when $\mathrm{p}$-value $<0.05$.

\section{Results}

\section{Patient characteristics and clinical predictors}

Seventy HNSCC patients were included in this study (Table 1$)$. They were mainly male $(80 \%)$, with ages ranging from 20 to 90 (median 59 years). Tobacco use or alcohol consumption (current or past) were found in $87.1 \%$ and $82.9 \%$, respectively. Primary tumor sites included: oral cavity (52.9\%), larynx (30\%), oropharynx (11.4\%), and hypopharynx $(5.7 \%)$. Clinical tumor stage at diagnosis was cT1/cT2 in $38.6 \%$ of the cases and cT3/cT4 in $61.4 \%$ of the cases, and $58.6 \%$ of patients presented a clinically positive lymph node.

Surgery followed by radiotherapy was the treatment approach in $48.6 \%$ of the patients. The median follow up period for these patients was 29.2 months (range: 1 62.6 months). Recurrences occurred in 32 cases (45.7\%) and $7(10 \%)$ patients developed second primary tumors (SPT) in the upper aerodigestive tract (lung, tongue, esophagus and lip).

\section{Quantitative methylation-specific PCR in HNSCC samples}

Due to the scarcity of DNA quantity after bisulfite treatment of many samples and the number of genes selected, it would be virtually impossible to evaluate all possible candidate genes in all samples. So, we firstly decided to conduct an exploratory study, and then a more limited set of "best" genes would be used in an expanded cohort of samples. The first step was to verify the hypermethylation status of 19 genes in salivary rinse samples collected from healthy individuals (controls, $\mathrm{n}=20$ ). Although tumor and salivary rinse are not identical tissues, we used this method because formal biopsy of the 60 noncancer patients was not logistically feasible and other studies have already shown that saliva is a reliable source of normal mucosa cells [20]. This analysis showed that TGF $\beta 2$ 2, CALCA, HIC1, SOCS1, 
Table 1 Demographic and clinical characteristics of HNSCC patients included in the study $(n=70)$

\begin{tabular}{|c|c|c|c|}
\hline Characteristic & & $\mathrm{N}$ & $\%$ \\
\hline & Median, range & $59.2-90$ & \\
\hline \multirow[t]{2}{*}{ Age } & $>60$ y.o. & 38 & 54.3 \\
\hline & $\leq 60$ y.o. & 32 & 45.7 \\
\hline \multirow[t]{2}{*}{ Gender } & Male & 56 & 80.0 \\
\hline & Female & 14 & 20.0 \\
\hline Tobacco & Yes & 61 & 87.1 \\
\hline Consumption & No & 9 & 12.9 \\
\hline Alcohol & Yes & 58 & 82.9 \\
\hline Consumption & No & 12 & 17.1 \\
\hline Tumor & Oral cavity & 37 & 52.9 \\
\hline \multirow[t]{3}{*}{ Site } & Larynx & 21 & 30.0 \\
\hline & Oropharynx & 8 & 11.4 \\
\hline & Hypopharynx & 4 & 5.7 \\
\hline \multirow[t]{2}{*}{ cT Stage } & $\mathrm{cT} 1 / \mathrm{cT} 2$ & 27 & 38.6 \\
\hline & $\mathrm{cT3/cT4}$ & 43 & 61.4 \\
\hline \multirow[t]{2}{*}{ cN Stage } & cNO & 29 & 41.4 \\
\hline & $\mathrm{cN}+$ & 41 & 58.6 \\
\hline First curative & Surgery & 13 & 18.6 \\
\hline \multirow[t]{4}{*}{ treatment } & Radiotherapy & 3 & 4.3 \\
\hline & Surgery + Radio & 34 & 48.6 \\
\hline & Surgery + Radio + Chemo & 9 & 12.9 \\
\hline & Radio + Chemo & 11 & 15.7 \\
\hline Second primary & Yes & 7 & 10.0 \\
\hline Tumor & No & 63 & 90.0 \\
\hline \multirow[t]{2}{*}{ Recurrence } & Yes & 32 & 45.7 \\
\hline & No & 38 & 54.3 \\
\hline
\end{tabular}

RARß, COX2, CDH1, THBS1, HIN1, CDKN2B, UCHL1, $C C N D 2, M T 1 G$ and $D C C$ were frequently methylated in control samples, showing low specificity (Table 2). Therefore, these 14 genes were excluded from the study. The methylation pattern of the remaining 7 genes, identified as unmethylated in control samples, was profiled in 20
HNSCC specimens. This analysis revealed that hypermethylation of CCNA1, DAPK, MGMT, SFRP1 and TIMP3 was frequent in head and neck tumor (40-70\%). So, these 5 genes that could better distinguish HNSCC tumors from control samples were selected to be tested in the expanded cohort of HNSCC specimens $(\mathrm{n}=70)$ and control subjects $(\mathrm{n}=60)$.

By the end, CCNA1 was found methylated in $33 \%$ of HNSCC cases, DAPK in 51\%, MGMT in $21 \%$, SFRP 1 in $62 \%$ and TIMP3 in 53\% (Table 2, Figure 1). Noteworthy, complete coverage of every sample for every possible methylation marker selected was not possible due to either low quantity of total extracted DNA or limited DNA amount after bisulfite treatment. So, all the genes could not be run on all samples because of lack of DNA. This analysis demonstrated these genes as able to distinguish HNSCC tumors from control samples with high specificity $(>96 \%)$ and sensitivity (21-62\%) (Table 2). Furthermore, 54 HNSCC samples (77.1\%) showed hypermethylation in at least one of these five genes.

\section{Association between aberrant methylation and patient characteristics}

The methylation pattern of CCNA1, DAPK, MGMT, SFRP1 and TIMP3 as well as a panel containing all these 5 genes was analyzed for potential associations with clinical and pathological characteristics of HNSCC patients, including age, gender, tobacco consumption, alcohol consumption, primary tumor site, $\mathrm{T}$ stage, $\mathrm{N}$ stage, lymph vascular invasion, perineural invasion, surgical margins status, lymph node involvement and second primary tumor development.

This analysis showed that the hypermethylation of $C C$ NA1 $(\mathrm{p}=0.007)$ and SFRP1 $(\mathrm{p}=0.024)$ was associated with age greater than 60 years old, while the hypermethylation of TIMP3 was associated with hypopharynx tumors $(\mathrm{p}=0.023$; Table 3). Furthermore, aberrant methylation of CCNA1 and TIMP3 was significantly correlated to the development of SPT ( $\mathrm{p}=0.004$ and $\mathrm{p}=0.012$, respectively). Of the 7 patients who developed SPT, 86\% (6/7) had CCNA1 methylated, while $100 \%$ showed TIMP3 methylation (Table 3). There was no other significant association

Table 2 Comparison of hypermethylation detection on HNSCC tumor specimens and normal control salivary rinse samples

\begin{tabular}{|c|c|c|c|c|c|c|}
\hline \multirow[t]{2}{*}{ Genes } & \multicolumn{2}{|c|}{ Control } & \multicolumn{2}{|c|}{ HNSCC } & \multirow{2}{*}{$\begin{array}{l}\text { Specificity\% } \\
(95 \% \mathrm{Cl})\end{array}$} & \multirow{2}{*}{$\begin{array}{c}\text { Senstivity\% } \\
(95 \% \mathrm{Cl})\end{array}$} \\
\hline & Cases (n) & M n (\%) & Cases (n) & $M n(\%)$ & & \\
\hline CCNA1 & 60 & $2(3)$ & 67 & $22(33)$ & $97(93-101)$ & $33(21-45)$ \\
\hline DAPK & 39 & $1(3)$ & 68 & $35(51)$ & $97(93-101)$ & $51(38-64)$ \\
\hline MGMT & 57 & $2(4)$ & 67 & $14(21)$ & $96(91-101)$ & $21(11-31)$ \\
\hline SFRP1 & 20 & $0(0)$ & 58 & $36(62)$ & 100 & $62(50-74)$ \\
\hline TIMP3 & 60 & $2(3)$ & 70 & $37(53)$ & $97(93-101)$ & $53(40-66)$ \\
\hline
\end{tabular}



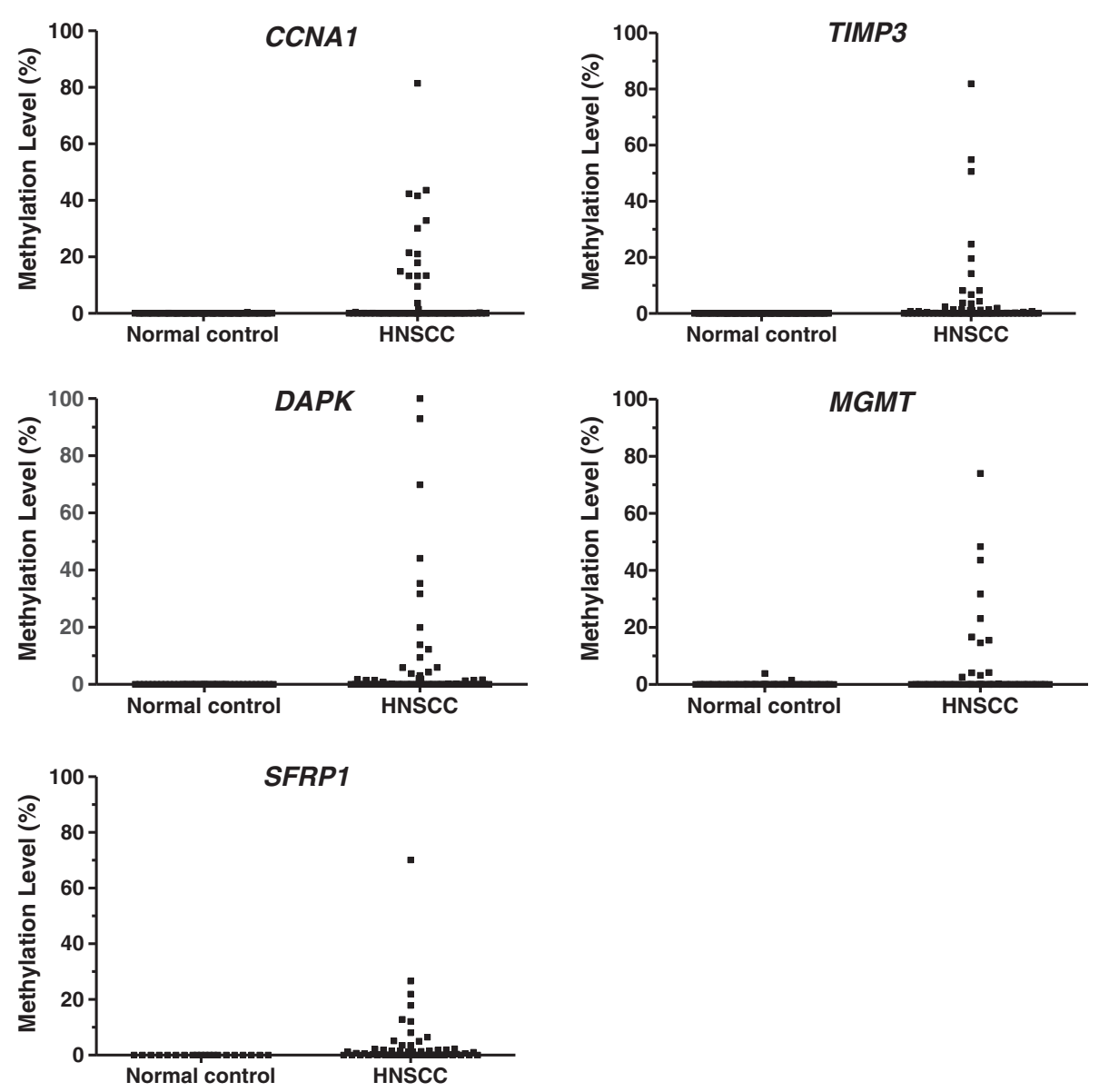

Figure 1 The methylation rates of five genes (CCNA1, TIMP3, DAPK, MGMT and SFRP1) in normal controls and HNSCC samples. $x$-axis, proportion of methylated cases/tested cases; $y$-axis, quantity of hypermethylation (gene of interest/ACTB $\times 100$ ).

between gene hypermethylation and clinical and pathological characteristics of HNSCC patients.

Overall survival at 3 years was $47 \%$. No statistical significance was observed on the overall survival according to gender, tumor site and tobacco and alcohol use. But, as expected, the overall survival was better for those patients with early $\mathrm{T}$ stage $(63.0 \%$ initial vs. $36.8 \%$ advanced, $\mathrm{p}=$ $0.010)$ and negative $\mathrm{N}$ stage $(64.9 \%$ negative vs. $34.4 \%$ positive, $\mathrm{p}=0.001)$. No significant association was found between any other clinical markers and overall survival rates (Additional file 2: Table S2).

The analyses of overall survival were not able to identify any significant associations with the hypermethylation status of the five investigated genes in the HNSCC cases (Table 4), but, given the association between CCNA1 and TIMP3 hypermethylation and the development of SPT, the second primary tumor-free survival at 3-years was also evaluated (Table 4). Notably, HNSCC patients carrying tumors with methylated versions of CCNA1 and TIMP3 genes experienced an increased probability of developing $\mathrm{SPT}$ in comparison to patients whose tumors presented unmethylated versions of these two genes (CCNA1: 38.0\% methylated vs. $2.2 \%$ unmethylated, $\mathrm{p}=0.001$; and TIMP3: $25.1 \%$ methylated vs. $0 \%$ unmethylated, $\mathrm{p}=0.007$; log-rank test; Figure 2). A significantly higher risk of developing second primary tumors was observed for patients carrying tumors with methylated CCNA1 $(\mathrm{HR}=13.95,95 \% \mathrm{CI}=$ 1.67-116.33; $\mathrm{p}=0.015$ ), but the same was not observed for methylated TIMP3 tumors $(\mathrm{HR}=68.62$, 95\% CI $=0.15$ 30191.20; $\mathrm{p}=0.173$ ). The independent effect of CCNA1 methylation and significant clinical features on the probability of second primary tumor development was analyzed using a Cox regression model. This multivariate analysis was not able to detect any independent factor.

\section{Discussion}

The treatment approach and consequently the prognosis of HNSCC patients is mainly determined by the stage at presentation through the evaluation of the tumor extent, the presence of lymph-node and distant metastases and several histopathological parameters evaluated after surgery. Disappointingly, despite the evolution in patient management, 
Table 3 Correlation between clinical and pathological characteristics of HNSCC patients and aberrant methylation profile of CCNA1, DAPK, MGMT, SFRP1, TIMP3 and the 5-gene panel in HNSCC samples

\begin{tabular}{|c|c|c|c|c|c|c|c|c|c|c|c|c|c|c|c|c|}
\hline \multirow[t]{2}{*}{ Characteristics } & \multirow[t]{2}{*}{ Category } & \multicolumn{2}{|l|}{ CCNA1 } & \multirow[t]{2}{*}{ p-value } & \multicolumn{2}{|l|}{$D A P K$} & \multirow[t]{2}{*}{$p$-value } & \multicolumn{2}{|l|}{ SFRP1 } & \multirow[t]{2}{*}{$p$-value } & \multicolumn{2}{|l|}{ TIMP3 } & \multirow[t]{2}{*}{$p$-value } & \multirow{2}{*}{$\begin{array}{c}\text { 5-gene } \\
\text { U }\end{array}$} & \multirow{2}{*}{$\begin{array}{c}\text { panel } \\
\text { M }\end{array}$} & \multirow[t]{2}{*}{ p-value } \\
\hline & & $\mathbf{U}$ & M & & $\mathbf{U}$ & M & & $\mathbf{U}$ & M & & U & M & & & & \\
\hline \multirow[t]{2}{*}{ Age } & $<60$ yrs & $30(81)$ & $7(19)$ & 0.007 & $20(53)$ & $18(48)$ & 0.446 & $17(50)$ & $17(50)$ & 0.024 & $22(56)$ & $17(44)$ & 0.081 & $13(34.2)$ & $25(65.8)$ & 0.016 \\
\hline & $>60$ yrs & $15(50)$ & $15(50)$ & & $13(43)$ & $17(57)$ & & $5(21)$ & $19(79)$ & & $11(36)$ & $20(64)$ & & $3(9.7)$ & $28(90.3)$ & \\
\hline \multirow[t]{4}{*}{ Tumor site } & Oral cavity & $26(74)$ & $9(26)$ & $0.530^{\mathrm{a}}$ & $20(56)$ & $16(44)$ & $0.609^{a}$ & $15(50)$ & $15(50)$ & $0.055^{a}$ & $23(62)$ & $14(38)$ & $0.023^{a}$ & $9(25.0)$ & $27(75.0)$ & 0.419 \\
\hline & Larynx & $13(62)$ & $8(39)$ & & $8(38)$ & $13(62)$ & & $5(29)$ & $12(71)$ & & $7(33)$ & $14(64)$ & & $6(28.6)$ & $15(71.4)$ & \\
\hline & Oropharynx & $4(57)$ & $3(43)$ & & $3(43)$ & $4(57)$ & & $0(0)$ & $7(100)$ & & $1(13)$ & $7(87)$ & & $0(0)$ & $8(100)$ & \\
\hline & Hypopharynx & $2(50)$ & $2(50)$ & & $2(50)$ & $2(50)$ & & $2(50)$ & $2(50)$ & & $2(50)$ & $2(50)$ & & $1(25)$ & $3(75)$ & \\
\hline \multirow[t]{2}{*}{ Second primary tumor } & Absent & $44(73)$ & $16(27)$ & $0.004^{\mathrm{a}}$ & $31(51)$ & $30(49)$ & $0.429^{a}$ & $21(41)$ & $30(59)$ & $0.235^{a}$ & $33(52)$ & $30(48)$ & $0.012^{\mathrm{a}}$ & $16(25.8)$ & $46(74.2)$ & $0.188^{a}$ \\
\hline & Present & $1(14)$ & $6(86)$ & & $2(29)$ & $5(71)$ & & $1(14)$ & $6(86)$ & & $0(0)$ & $7(100)$ & & $0(0)$ & $7(100)$ & \\
\hline
\end{tabular}

$\mathrm{U}$ - unmethylated, $\mathrm{n}(\%) ; \mathrm{M}$ - methylated, $\mathrm{n}(\%),{ }^{\mathrm{a}}$ - $\mathrm{p}$-value calculated by Fisher's Exact Test. Numbers in bold number reflect statistically significant associations. 
Table 4 3-year overall survival and SPT-free survival rates according to the methylation status of the five selected genes and the 5-gene panel

\begin{tabular}{cccccc}
\hline Variables & $\begin{array}{c}\text { Methylation } \\
\text { status }\end{array}$ & $\begin{array}{c}\text { Overall } \\
\text { survival (\%) }\end{array}$ & $\mathbf{p}$ & $\begin{array}{c}\text { SPT-free } \\
\text { survival (\%) }\end{array}$ & $\mathbf{p}$ \\
\hline CCNA1 & U & 50.2 & 0.578 & 97.8 & $\mathbf{0 . 0 0 1}$ \\
DAPK & $\mathrm{M}$ & 34.5 & & 62.0 & \\
& $\mathrm{U}$ & 46.3 & 0.914 & 94.1 & 0.292 \\
MGMT & $\mathrm{M}$ & 45.7 & & 79.7 & \\
& $\mathrm{U}$ & 44.4 & 0.714 & 88.5 & 0.527 \\
SFRP1 & $\mathrm{M}$ & 48.2 & & 77.4 & \\
& $\mathrm{U}$ & 43.1 & 0.494 & 91.7 & 0.160 \\
TIMP3 & $\mathrm{M}$ & 43.9 & & 79.1 & \\
& $\mathrm{U}$ & 52.8 & 0.183 & 100 & $\mathbf{0 . 0 0 7}$ \\
& $\mathrm{M}$ & 40.5 & & 74.9 & \\
5-gene panel & $\mathrm{U}$ & 48.2 & 0.176 & 100 & 0.091 \\
& $\mathrm{M}$ & 38.9 & & 81.4 & \\
\hline
\end{tabular}

SPT, Second Primary Tumor; $\mathrm{U}$ - unmethylated; $\mathrm{M}$ - methylated. Numbers in bold number reflect statistically significant associations.

the overall survival of HNSCC has not markedly improved in recent decades [34]. In HNSCC, late diagnosis and the development of loco-regional recurrences are responsible for the poor prognosis observed. Besides them, another common reason for treatment failure in HNSCC cases is the development of second primary tumors (SPT) [4]. HNSCC patients show a 10-30 times greater chance of developing SPT [35].

In order to identify new molecular markers for prognosis of HNSCC patients, we used QMSP to assess the methylation status of 19 genes in HNSCC samples collected during surgical treatment. CCNA1, DAPK, MGMT, SFRP1 and TIMP3 were found frequently and specifically methylated in HNSCC specimens.

A small number of studies have reported a relatively frequent hypermethylation of these genes in HNSCC [36-46]. According to them, CCNA1 methylation could be detected in $34-53 \%$ of HNSCC cases evaluated in three studies, while DAPK gene methylation was detected in $21-74 \%$ of tumors examined by six studies. MGMT hypermethylation was detected in $22-50 \%$ of tumors examined by four independent research groups, SFRP1 was methylated in 24$35 \%$ of tumors examined in two different studies and TIMP3 methylation was detected in $10-72 \%$ of tumors evaluated in two studies. Consistent with this, we also found CCNA1 (33\%), DAPK (51\%), MGMT (21\%) and TIMP3 (53\%) frequently methylated in HNSCC samples. In contrast, we were able to detect SFRP1 methylation in $62 \%$ of the HNSCC samples, a frequency higher than observed previously.

To our knowledge, this is the first study to show a significant association between the presence of TIMP3 and CCNA1 aberrant methylation in the primary $\mathrm{HN}$ carcinomas and the development of SPT. Tissue inhibitor of metalloproteinases 3 (TIMP3) belongs to a family of genes that inhibit matrix metalloproteinases (MMPs), a group of peptidases involved in degradation of the extracellular matrix (ECM). TIMP3 exerts its anti-proteolytic function either at the invasion front of an infiltrating tumor to quench tumor-associated ECM degrading activity or in the stroma itself, where soluble proteases liberate ECM-tethered factors that assist the cancer cell in migration and invasion. Numerous studies have indicated that TIMPs inhibit cellular invasion, tumorigenesis, metastasis and angiogenesis [47]. Therefore, the hypermethylation of TIMP3 and, consequently, its transcriptional repression would hinder its function as inhibitors of matrix metalloproteinases (MMPs), thus contributing to the degradation of the extracellular matrix. A previous study [48] reported that an increased expression of $M M P 9$ in the histologically negative surgical margins of HNSCC was associated with the development of SPT. MMP9 encodes a gelatinase that degrades type IV collagen, the major constituent of basement membrane. The lateral spread of clones from malignant tumors involves the occurrence of multiple factors necessary for cell motility to penetrate the extracellular matrix [49]. Thus, the inhibition of TIMP3 by hypermethylation and, consequently, the loss of the regulating activity of the MMP extracellular matrix degradation may contribute to the development of SPT. Sun et al. [50] showed the detection of TIMP3 hypermethylation in salivary rinse samples collected at diagnoses associated with local recurrence-free survival in patients with HNSCC. In a recent study, our group demonstrated that the detection of TIMP3 hypermethylation in salivary rinse collected, not only at diagnosis, but also six months after the last curative treatment is an independent prognostic factor for HNSCC patients [24].

The protein encoded by cyclin A1 (CCNA1) belongs to the highly conserved cyclin family, whose members are characterized by a dramatic periodicity in protein abundance through the cell cycle. Cyclins function as regulators of CDK kinases. CCNA1 cyclin was found to bind to important cell cycle regulators, such as Rb family proteins, transcription factor E2F-1, and the p21 family proteins $[51,52]$. A previous study found promoter hypermethylation of the cyclin A1 gene in $45 \%$ of primary HNSCC tissue samples evaluated, as well as in multiple cell lines. Rivera et al. [53] could show that CCNA1 is a downstream target of $p 53$ and it can induce apoptosis and G2M arrest if up-regulated. We sought that loss of CCNA1 expression though promoter hypermethylation might be involved in early oncogenic events, down regulating apoptosis and cell cycle arrest, therefore contributing to a proliferative advantage to cells in precursor lesions and giving rise to the expansion of a clonal population of progenitor cells susceptible to new oncogenic events. These lesions can 

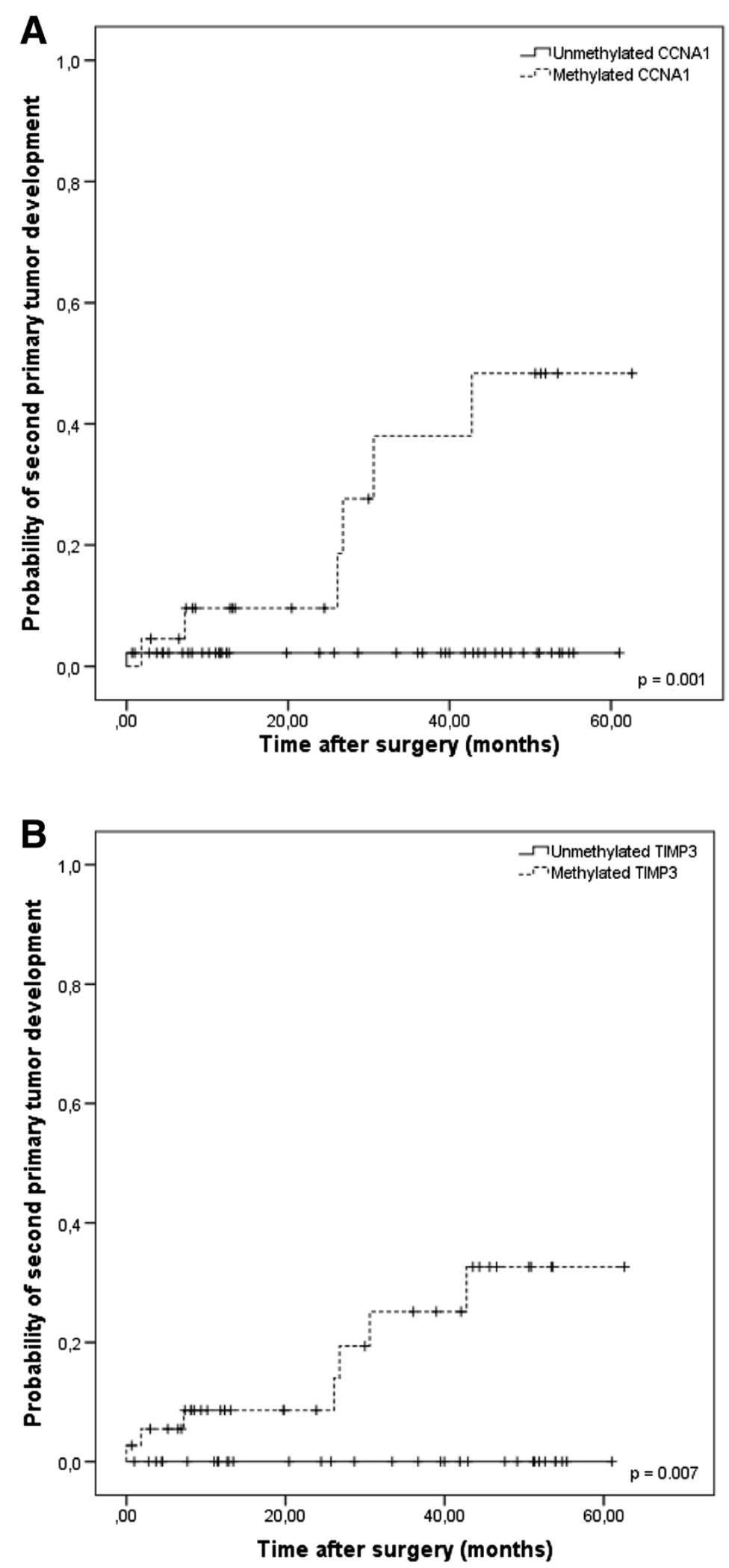

Figure 2 Kaplan-Meier curve comparing the probability of second primary tumor development in patients carrying methylated or unmethylated versions of CCNA1 (A) and TIMP3 (B) in HNSCC samples. 
accumulate oncogenic events to give rise to the development of SPT.

Although the presence of fields with a high risk of development of second primary tumors is indicated by certain clinical lesions such as erythroplakia and leukoplakia [54], most premalignant fields are not clinically detectable and others can extend well beyond the clinically visible area [55,56]. Previous studies have already supported the theory of field cancerization, which refers to the presence of malignant or premalignant changes in the entire field of apparently normal tissue adjacent to the tumor in response to a carcinogen exposition [11]. According to this theory, the development of SPT represents the progression of multiple separate genetically altered mucosal foci. However, recent studies have been reporting that at least a proportion of these SPT arise from residual portions of a single contiguous preneoplastic field after the complete resection of the index tumor. According to them, a stem cell acquires genetic alterations and forms a patch with genetically altered daughter cells. As a result of subsequent genetic alterations, the stem cell escapes normal growth control, gains growth advantage, and develops into an expanding clone. The lesion laterally displaces the normal epithelium and additional genetic hits give rise to various subclones within the field. Different clones diverge at a certain point with respect to genetic alterations but do share a common clonal origin, and as a result of the process of clonal divergence and selection, eventually a subclone evolves into invasive cancer [57]. Our results suggest that some of these genetic alterations could be the aberrant methylation of CCNA1 and TIMP3 genes. Along the same line, our group has also demonstrated that the overexpression of MMP9 in histologically negative HNSCC margins was significantly correlated to a high risk of developing SPT [48].

\section{Conclusions}

In summary, our results showed that CCNA1, DAPK, $M G M T$, SFRP1 and TIMP3 are frequently and specifically hypermethylated in HNSCC samples. In spite of the small number of samples evaluated, we demonstrated for the first time that the hypermethylation of CCNA1 and TIMP3 are significantly correlated to the development of SPT. Based on these results, we may speculate that the methylation pattern of these genes in HNSCC, could be a helpful marker for the identification of subjects at risk of new neoplastic evolution. Of note, the confidence intervals observed in the analyses of hazard ratios are large and this may be due to the small sample size evaluated. Despite of this, the statistically significance observed in the association through the log-rank analyses for both genes and in the Cox regression for CCNA1 and STP denotes the potential of these markers as clinically relevant. The possibility of evaluating the primary tumor to predict the risk for the development of second primary tumors is relevant given the difficulty of identifying premalignant fields in the upper aerodigestive tract and the fact that the whole mucosa would have to be assessed, representing a very invasive diagnostic method. Further validation of these results requires studies with larger patient groups and longer follow-up period, but by achieving a good predictive negative value, this QMSP approach could constitute an alternative in predicting the risk for the development of SPT, allowing the use of preventive measures, with more frequent clinical monitoring of these patients and maybe select patients candidates for adjuvant treatment.

\section{Additional files}

Additional file 1: Table S1. Primers and probes used in the QMSP assays.

Additional file 2: Table S2. SPT control and overall survival rates

according to the clinical variables.

\section{Competing interests}

The authors declare that they have no competing interests.

\section{Authors' contributions}

MMR and ACC performed the research, collected clinical data, analyzed data and wrote the paper. ALB performed some of the wet bench experiments. CZO performed the statistical analysis. ALC and LFK recruited patients and collected tissue samples. ALV designed and coordinated the study and wrote the paper. All authors have read and approved the final manuscript.

\section{Acknowledgements}

This study was funded by Fundação de Amparo à Pesquisa do Estado de São Paulo (FAPESP). M. M. R was recipient of scholarship from Coordenação de Aperfeiçoamento de Pessoal de Nível Superior (CAPES) and A. C. C. and A. C. C. was recipient of scholarship from Fundação de Amparo à Pesquisa do Estado de São Paulo (FAPESP). A. L. C. has a National Counsel of Technological and Scientific Development (CNPq) scholarship. Tissues were obtained from the tumor bank of A. C. Camargo Hospital/Antonio Prudente Foundation.

\section{Author details}

${ }^{1}$ Cancer Molecular Biology Laboratory, Department of Biological Sciences, Federal University of São Paulo, 04039-020, São Paulo, Brazil. 'Statistics and Epidemiology Center, Barretos Cancer Hospital, 14784-400, Barretos, Brazil. ${ }^{3}$ Departament of Head and Neck Surgery, A.C. Camargo Hospital, 01509-010, São Paulo, Brazil. ${ }^{4}$ Departament of Head and Neck Surgery, Barretos Cancer Hospital, 14784-400, Barretos, Brazil. ${ }^{5}$ Cancer and Stem Cell Biology Program, Duke-NUS Graduate Medical School, 169857, Singapore, Singapore.

Received: 7 November 2013 Accepted: 17 December 2013 Published: 20 December 2013

\section{References}

1. Whaley JT, Indelicato DJ, Morris CG, Hinerman RW, Amdur RJ, Mendenhall WM, Keole SR, Marcus RB Jr: Ewing tumors of the head and neck. Am J Clin Oncol 2010, 33:321-326.

2. Leemans CR, Braakhuis BJ, Brakenhoff RH: The molecular biology of head and neck cancer. Nat Rev Cancer 2011, 11:9-22

3. Rabbani A, Hinerman RW, Schmalfuss IM, Amdur RJ, Morris CG, Peters KR, Robbins KT, Mendenhall WM: Radiotherapy and concomitant intraarterial cisplatin (RADPLAT) for advanced squamous cell carcinomas of the head and neck. Am J Clin Oncol 2007, 30:283-286.

4. Sturgis EM, Miller RH: Second primary malignancies in the head and neck cancer patient. Ann Otol Rhinol Laryngol 1995, 104:946-954.

5. Braakhuis BJ, Leemans $C R$, Brakenhoff $\mathrm{RH}$ : A genetic progression model of oral cancer: current evidence and clinical implications. J Oral Pathol Med 2004, 33:317-322. 
6. Kelloff GJ, Lippman SM, Dannenberg AJ, Sigman CC, Pearce HL, Reid BJ, Szabo E, Jordan VC, Spitz MR, Mills GB, et al: Progress in chemoprevention drug development: the promise of molecular biomarkers for prevention of intraepithelial neoplasia and cancer-a plan to move forward. Clin Cancer Res 2006, 12:3661-3697.

7. Priante AV, Castilho EC, Kowalski LP: Second primary tumors in patients with head and neck cancer. Curr Oncol Rep 2011, 13:132-137.

8. Franchin G, Minatel E, Gobitti C, Talamini R, Vaccher E, Sartor G, Politi D, Trovo MG, Barzan L: Radiotherapy for patients with early-stage glottic carcinoma: univariate and multivariate analyses in a group of consecutive, unselected patients. Cancer 2003, 98:765-772.

9. Lee JH, Machtay M, McKenna MG, Weinstein GS, Markiewicz DA, Krisch RE, Kligerman MM: Radiotherapy with 6-megavolt photons for early glottic carcinoma: potential impact of extension to the posterior vocal cord. Am J Otolaryngol 2001, 22:43-54.

10. Kowalski LP, Batista MB, Santos CR, Scopel AA, Salvajoli JV, Novaes PE, Trippe N: Prognostic factors in glottic carcinoma clinical stage I and II treated by surgery or radiotherapy. Am J Otolaryngol 1993, 14:122-127.

11. Slaughter DP, Southwick HW, Smejkal W: Field cancerization in oral stratified squamous epithelium; clinical implications of multicentric origin. Cancer 1953, 6:963-968.

12. Homann N, Nees M, Conradt C, Dietz A, Weidauer H, Maier H, Bosch FX: Overexpression of p53 in tumor-distant epithelia of head and neck cancer patients is associated with an increased incidence of second primary carcinoma. Clin Cancer Res 2001, 7:290-296.

13. Lei D, Sturgis EM, Liu Z, Zafereo ME, Wei Q, Li G: Genetic polymorphisms of p21 and risk of second primary malignancy in patients with index squamous cell carcinoma of the head and neck. Carcinogenesis 2010, 31:222-227

14. Zafereo ME, Sturgis EM, Aleem S, Chaung K, Wei Q, Li G: Glutathione S-transferase polymorphisms and risk of second primary malignancy after index squamous cell carcinoma of the head and neck. Cancer Prev Res (Phila) 2009, 2:432-439.

15. Jones PA, Baylin SB: The fundamental role of epigenetic events in cancer. Nat Rev Genet 2002, 3:415-428.

16. Herman JG, Baylin SB: Gene silencing in cancer in association with promoter hypermethylation. N Engl J Med 2003, 349:2042-2054.

17. Geiman TM, Robertson KD: Chromatin remodeling, histone modifications, and DNA methylation-how does it all fit together? J Cell Biochem 2002, 87:117-125

18. Brabender J, Usadel H, Danenberg KD, Metzger R, Schneider PM, Lord RV, Wickramasinghe K, Lum CE, Park J, Salonga D, et al: Adenomatous polyposis coli gene promoter hypermethylation in non-small cell lung cancer is associated with survival. Oncogene 2001, 20:3528-3532.

19. Brait M, Begum S, Carvalho AL, Dasgupta S, Vettore AL, Czerniak B, Caballero OL, Westra WH, Sidransky D, Hoque MO: Aberrant promoter methylation of multiple genes during pathogenesis of bladder cancer. Cancer Epidemiol Biomarkers Prev 2008, 17:2786-2794

20. Carvalho AL, Jeronimo C, Kim MM, Henrique R, Zhang Z, Hoque MO, Chang S, Brait M, Nayak CS, Jiang WW, et al: Evaluation of promoter hypermethylation detection in body fluids as a screening/diagnosis tool for head and neck squamous cell carcinoma. Clin Cancer Res 2008, 14:97-107.

21. Longo AL, Rettori MM, de Carvalho AC, Kowalski LP, Carvalho AL, Vettore AL: Evaluation of the methylation profile of exfoliated cell samples from head and neck squamous cell carcinoma patients. Head Neck 2013 [Epub ahead of print]

22. Hou P, Ji M, Yang B, Chen Z, Qiu J, Shi X, Lu Z: Quantitative analysis of promoter hypermethylation in multiple genes in osteosarcoma. Cancer 2006, 106:1602-1609.

23. Issa JP, Ottaviano YL, Celano P, Hamilton SR, Davidson NE, Baylin SB: Methylation of the oestrogen receptor $\mathrm{CPG}$ island links ageing and neoplasia in human colon. Nat Genet 1994, 7:536-540.

24. Rettori MM, de Carvalho AC, Bomfim Longo AL, de Oliveira CZ, Kowalski LP, Carvalho AL, Vettore AL: Prognostic significance of TIMP3 hypermethylation in post-treatment salivary rinse from head and neck squamous cell carcinoma patients. Carcinogenesis 2013, 34:20-27.

25. Vidal DO, Paixao VA, Brait M, Souto EX, Caballero OL, Lopes LF, Vettore AL: Aberrant methylation in pediatric myelodysplastic syndrome. Leuk Res 2007, 31:175-181.

26. Eads CA, Lord RV, Wickramasinghe K, Long TI, Kurumboor SK, Bernstein L Peters JH, DeMeester SR, DeMeester TR, Skinner KA, Laird PW: Epigenetic patterns in the progression of esophageal adenocarcinoma. Cancer Res 2001, 61:3410-3418

27. Harden SV, Tokumaru Y, Westra WH, Goodman S, Ahrendt SA, Yang SC Sidransky D: Gene promoter hypermethylation in tumors and lymph nodes of stage I lung cancer patients. Clin Cancer Res 2003, 9:1370-1375.

28. Hoque MO, Topaloglu O, Begum S, Henrique R, Rosenbaum E, Van Criekinge W, Westra WH, Sidransky D: Quantitative methylation-specific polymerase chain reaction gene patterns in urine sediment distinguish prostate cancer patients from control subjects. J Clin Oncol 2005, 23:6569-6575.

29. Fackler MJ, McVeigh M, Mehrotra J, Blum MA, Lange J, Lapides A, Garrett E Argani P, Sukumar S: Quantitative multiplex methylation-specific PCR assay for the detection of promoter hypermethylation in multiple genes in breast cancer. Cancer Res 2004, 64:4442-4452.

30. Weisenberger DJ, Siegmund KD, Campan M, Young J, Long TI, Faasse MA, Kang GH, Widschwendter M, Weener D, Buchanan D, et al: CpG island methylator phenotype underlies sporadic microsatellite instability and is tightly associated with BRAF mutation in colorectal cancer. Nat Genet 2006, 38:787-793.

31. Muller HM, Widschwendter A, Fiegl H, Ivarsson L, Goebel G, Perkmann E, Marth C, Widschwendter M: DNA methylation in serum of breast cancer patients: an independent prognostic marker. Cancer Res 2003, 63:7641-7645.

32. de Carvalho F, Colleoni GW, Almeida MS, Carvalho AL, Vettore AL: TGFbetaR2 aberrant methylation is a potential prognostic marker and therapeutic target in multiple myeloma. Int J Cancer 2009, 125:1985-1991.

33. Warren S, Gates O: Multiple primary malignant tumors. A survey of the literature and a statistical study. Am J Cancer 1932, 16:1358-1414.

34. Hinerman RW, Mendenhall WM, Morris CG, Amdur RJ, Werning JW, Villaret DB: Postoperative irradiation for squamous cell carcinoma of the oral cavity: 35-year experience. Head Neck 2004, 26:984-994.

35. Fijuth J, Mazeron JJ, Le Pechoux C, Piedbois P, Martin M, Haddad E, Calitchi E, Pierquin B, Le Bourgeois JP: Second head and neck cancers following radiation therapy of $\mathrm{T} 1$ and $\mathrm{T} 2$ cancers of the oral cavity and oropharynx. Int J Radiat Oncol Biol Phys 1992, 24:59-64.

36. Goldenberg D, Harden S, Masayesva BG, Ha P, Benoit N, Westra WH, Koch WM, Sidransky D, Califano JA: Intraoperative molecular margin analysis in head and neck cancer. Arch Otolaryngol Head Neck Surg 2008, 130:39-44.

37. Hall GL, Shaw RJ, Field EA, Rogers SN: Sutton, DN Woolgar, JA, Lowe D, Liloglou T, Field JK, Risk JM: p16 Promoter methylation is a potential predictor of malignant transformation in oral epithelial dysplasia. Cancer Epidemiol Biomarkers Prev 2012, 17:2174-2179.

38. Liu Y, Zhou ZT, He QB, Jiang WW: DAPK promoter hypermethylation in tissues and body fluids of oral precancer patients. Med Oncol 2012, 29:729-733.

39. Martone T, Gillio-Tos A, De Marco L, Fiano V, Maule M, Cavalot A, Garzaro M, Merletti F, Cortesina G: Association between hypermethylated tumor and paired surgical margins in head and neck squamous cell carcinomas. Clin Cancer Res 2007, 13:5089-5094.

40. Sogabe Y, Suzuki H, Toyota M, Ogi K, Imai T, Nojima M, Sasaki Y, Hiratsuka H, Tokino T: Epigenetic inactivation of SFRP genes in oral squamous cell carcinoma. Int J Oncol 2009, 32:1253-1261.

41. Supic G, Kozomara R, Jovic N, Zeljic K, Magic Z: Prognostic significance of tumor-related genes hypermethylation detected in cancer-free surgical margins of oral squamous cell carcinomas. Oral Oncol 2011, 47:702-708.

42. Tan HK, Saulnier P, Auperin A, Lacroix L, Casiraghi O, Janot F, Fouret $P$, Temam S: Quantitative methylation analyses of resection margins predict local recurrences and disease-specific deaths in patients with head and neck squamous cell carcinomas. Br J Cancer 2008, 99:357-363.

43. Weiss D, Basel T, Sachse F, Braeuninger A, Rudack C: Promoter methylation of cyclin A1 is associated with human papillomavirus 16 induced head and neck squamous cell carcinoma independently of p53 mutation. Mol Carcinog 2011, 50:680-688

44. Nayak CS, Carvalho AL, Jeronimo C, Henrique R, Kim MM, Hoque MO, Chang S, Jiang WW, Koch W, Westra W, et al: Positive correlation of tissue inhibitor of metalloproteinase-3 and death-associated protein kinase hypermethylation in head and neck squamous cell carcinoma. Laryngoscope 2007, 117:1376-1380.

45. Taioli E, Ragin C, Wang XH, Chen J, Langevin SM, Brown AR, Gollin SM, Garte S, Sobol RW: Recurrence in oral and pharyngeal cancer is associated with quantitative MGMT promoter methylation. BMC Cancer 2009, 9:354.

46. Marsit CJ, Houseman EA, Nelson HH, Kelsey KT: Genetic and epigenetic tumor suppressor gene silencing are distinct molecular phenotypes 
driven by growth promoting mutations in nonsmall cell lung cancer. $J$ Cancer Epidemiol 2008, 2008:215809.

47. Gomez DE, Alonso DF, Yoshiji H, Thorgeirsson UP: Tissue inhibitors of metalloproteinases: structure, regulation and biological functions. Eur J Cell Biol 1997, 74:111-122.

48. de Carvalho AC, Kowalski LP, Campos AH, Soares FA, Carvalho AL, Vettore AL: Clinical significance of molecular alterations in histologically negative surgical margins of head and neck cancer patients. Oral Oncol 2012, 48:240-248.

49. Stetler-Stevenson WG, Aznavoorian S, Liotta LA: Tumor cell interactions with the extracellular matrix during invasion and metastasis. Annu Rev Cell Biol 1993, 9:541-573.

50. Sun W, Zaboli D, Wang H, Liu Y, Arnaoutakis D, Khan T, Khan Z, Koch WM, Califano JA: Detection of TIMP3 promoter hypermethylation in salivary rinse as an independent predictor of local recurrence-free survival in head and neck cancer. Clin Cancer Res 2012, 18:1082-1091.

51. Girard F, Strausfeld U, Fernandez A, Lamb NJ: Cyclin A is required for the onset of DNA replication in mammalian fibroblasts. Cell 1991, 67:1169-1179.

52. Pagano M, Pepperkok R, Verde F, Ansorge W, Draetta G: Cyclin A is required at two points in the human cell cycle. EMBO J 1992, 11:961-971.

53. Rivera A, Mavila A, Bayless KJ, Davis GE, Maxwell SA: Cyclin A1 is a p53-induced gene that mediates apoptosis, G2/M arrest, and mitotic catastrophe in renal, ovarian, and lung carcinoma cells. Cell Mol Life Sci 2006, 63:1425-1439.

54. Gonzalez-Moles MA, Scully C, Ruiz-Avila I: Molecular findings in oral premalignant fields: update on their diagnostic and clinical implications. Oral Dis 2012, 18:40-47.

55. Brennan JA, Mao L, Hruban RH, Boyle JO, Eby YJ, Koch WM, Goodman SN, Sidransky D: Molecular assessment of histopathological staging in squamous-cell carcinoma of the head and neck. N Engl J Med 1995, 332:429-435.

56. Poh CF, Zhang L, Anderson DW, Durham JS, Williams PM, Priddy RW, Berean KW, $\mathrm{Ng}$ S, Tseng OL, MacAulay C, Rosin MP: Fluorescence visualization detection of field alterations in tumor margins of oral cancer patients. Clin Cancer Res 2006, 12:6716-6722.

57. Braakhuis BJ, Tabor MP, Kummer JA, Leemans CR, Brakenhoff RH: A genetic explanation of Slaughter's concept of field cancerization: evidence and clinical implications. Cancer Res 2003, 63:1727-1730.

doi:10.1186/1479-5876-11-316

Cite this article as: Rettori et al: TIMP3 and CCNA1 hypermethylation in HNSCC is associated with an increased incidence of second primary tumors. Journal of Translational Medicine 2013 11:316.

\section{Submit your next manuscript to BioMed Central and take full advantage of:}

- Convenient online submission

- Thorough peer review

- No space constraints or color figure charges

- Immediate publication on acceptance

- Inclusion in PubMed, CAS, Scopus and Google Scholar

- Research which is freely available for redistribution 